JURNAL KAWISTARA

\begin{tabular}{lll}
\hline VOLUME 9 & No. 3, 22 Desember 2019 & Halaman 349-352 \\
\hline
\end{tabular}

\title{
GREGET BARU DESAIN PEMAHAMAN KORUPSI
}

\author{
Hendar Putranto \\ Dosen Fakultas Ilmu Komunikasi \\ Universitas Multimedia Nusantara \\ Surel: hendar2007@umn.ac.id
}

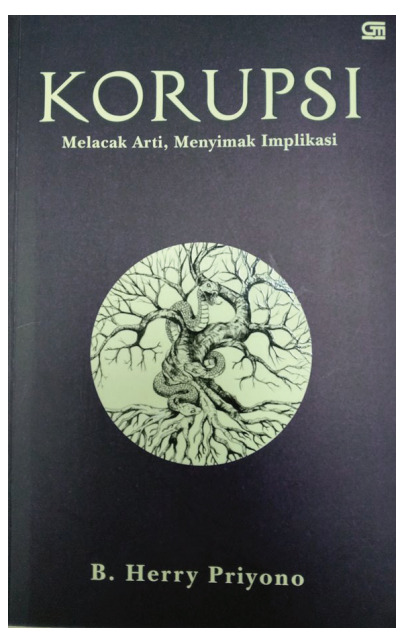

$\begin{array}{ll}\text { Judul Buku } & : \text { Korupsi: Melacak Arti, Menyimak Implikasi } \\ \text { Penulis } & : \text { B. Herry-Priyono } \\ \text { Penerbit } & : \text { Gramedia Pustaka Utama } \\ \text { Cetakan pertama } & \text { November 2018 } \\ \text { Tebal } & : \text { 664 halaman (termasuk Indeks) + xvi } \\ \text { ISBN } & : \text { 978-602-06-1905-7 } \\ \text { Resensi } & : \text { Hendar Putranto, dosen tetap Fakultas Ilmu } \\ & \text { Komunikasi } \\ \text { Institusi } & : \text { Universitas Multimedia Nusantara } \\ \text { Surel } & : \text { hendar2007@umn.ac.id }\end{array}$

\section{Darurat korupsi mengiris keutuhan tubuh negeri}

Penangkapan pucuk pimpinan sejumlah lembaga tinggi negara seperti Ketua Mahkamah Konstitusi, Ketua DPR, Ketua DPD, ketua

BPK, juga beberapa ketua partai politik, puluhan hakim, dan aparat pengadilan (nonhakim), ratusan anggota DPR dan kepala daerah, puluhan menteri dan pejabat eksekutif di bawah menteri, ratusan anggota DPRD kota/ kabupaten, juga ratusan orang dari pihak swasta selama periode 2004-2018 menegaskan situasi darurat korupsi di Indonesia pasca-reformasi. Menguatnya kelembagaan KPK, membaiknya Indeks Persepsi Korupsi Indonesia selama 20 tahun terakhir ini (Transparency International, 2018), berkembangnya inisiatif masyarakat sipil seperti Gerakan "Saya Perempuan Anti Korupsi" (SPAK) untuk mencegah korupsi (Gabrillin, 2019), serta meningkatnya kesadaran anti-korupsi di tingkat sekolah menengah dan pendidikan tinggi (ACCH, 2011; Bernie, 2019; Zain, 2019), ternyata tidak serta-merta mendorong terbentuknya 'perilaku antikorupsi' yang konsisten dari para pejabat publik negeri ini. Pertanyaannya, mengapa korupsi masih saja terus terjadi juga meskipun KPK sudah melakukan tindak pencegahan dan pemberantasan korupsi secara terstruktur, sistematis dan massif sejak berdirinya?

B. Herry-Priyono, seorang cendekia (dosen tetap) di STF Driyarkara sekaligus aktivis gerakan sosial pada paruh pertama 1990 secara mendalam merefleksikan keprihatinannya soal korupsi yang sejak lama menggerogoti kekayaan negeri ini. Keprihatinannya tidak berhenti di angan-angan belaka, namun berbuah produktif dan berujung pada solusi. Buku yang mulai ditulisnya sejak akhir tahun 2017 dan diselesaikan pada November 2018 ini merupakan ikhtiar mulianya untuk menyumbangkan kajian pustaka yang khas, solid, dan terukur untuk memahami keluasan definisi (arti) korupsi. Selain itu, sejumlah implikasi teoretis maupun praktis juga direfleksikannya berdasarkan keluasan arti korupsi sehingga menghasilkan beberapa pokok agenda pencegahan dan pemberantasan korupsi 
yang lebih punya greget. Kekhasan refleksi tersebut muncul misalnya dalam pendekatan yang diambil penulis yang lebih memilih pada "fokus keluasan guna menyediakan horizon dan menghasilkan gambaran sebuah 'ruang' ketimbang 'cakrawala." Penulis juga meminjam beragam bidang keilmuan yang menyoroti isu korupsi seperti studi klasik, sejarah, filsafat moral filsafat politik, teologi, politologi, ekonomika, sosiologi, antropologi, kriminologi, hukum, psikologi, dan beberapa disiplin ilmu lainnya. Menurut Herry-Priyono, beragam pendekatan ilmu yang digunakan hanyalah teropong untuk membantu memfokuskan analisis dan bukan gejala dari korupsi itu sendiri.

\section{Mendalilkan ragam arti korupsi lintas zaman}

Secara keseluruhan, buku ini memuat delapan bab tebal dengan pembagian dan isi pokok sebagai berikut: Pada bab pertama (hlm: 1-13) dijelaskan tentang tujuan keberadaan buku ini serta pegangan metodologis yang memandunya. Bab kedua, Perihal Arti dan Definisi (hlm: 15-58) menyajikan beberapa persoalan yang terlibat dalam pencarian definisi konsep korupsi, bukan untuk mematok atau membatasi pemahaman melainkan untuk memperkaya pengertian berdasarkan 'kekayaan arti korupsi yang muncul dari keragaman konteks dan tujuan yang melatarbelakangi corak definisi'. Pada bab ini juga disoroti tiga bias definisi yang umum dijumpai dalam studi korupsi yaitu bias hukum, bias sentrisme-negara, dan bias ekonomi (hlm: 57).

Babketiga, Sebelum Modernitas: Kemerosotan sebagai Paham Klasik Korupsi, membincang soal perkembangan arti konsep korupsi sejak zaman klasik Yunani dan Romawi kuno, pemikiran Aristoteles, kitab nasihat Kautilya dari India kuno, pemikiran teologis Agustinus, Thomas Aquinas, tradisi Islam misalnya dari Quran dan Hadis, juga dari risalah Muqaddimah karya Ibnu Khaldun, serta pemikiran Machiavelli pada zaman Renaisans. Pada bab ini, penulis menandaskan salah satu butir rangkumannya yaitu ditunjuk dengan istilah berbeda-beda dan bervariasi dalam isi perbuatan/praktik, korupsi bukanlah konsep khas dunia Barat dan modern melainkan dapat dikenali dalam tradisi Yunani dan Romawi kuno, India kuno, dan tradisi Islam' (hlm: 143). Sementara itu, pada bab keempat, Zaman Modern: Nostalgia dan Munculnya Paham Baru, penulis menunjukkan langkah pelacakan skematis pengertian korupsi sejak abad ke-17 hingga akhir abad ke-19, dengan menimbang gagasan sejumlah filsuf politik-moral, seperti Thomas Hobbes, Montesquieu, Adam Ferguson, Adam Smith, dan Jeremy Bentham. Pada epos zaman ini, korupsi sudah mulai bergerak dari konsepsi moral yang berurusan dengan rusaknya tatanan sosial kosmologis abstrak yang menjadi ciri khas zaman klasik hingga Abad Pertengahan menjadi konsep khusus bagi standar moral penggunaan kekuasaan/jabatan pemerintahan yang diselewengkan serta segala praktik monopoli dan privilese yang merusak tatanan dunia baru yang didasarkan pada aspirasi kesetaraan.

Pada bab kelima, Zaman Kontemporer: Penyelewengan Mandat dan Jabatan Publik, Herry-Priyono melihat secara gamblang terjadinya reduksi dari keragaman arti korupsi. Salah satu penyebabnya adalah translokasi kekuasaan (jabatan publik) dari mandat Tuhan menjadi mandat rakyat yang dianggap dan berkedudukan setara di hadapan hukum. Hukum di sini berciri politis sekaligus birokratis karena terkait erat dengan tatakelola pemerintahan dan organisasi. Selain itu, dengan menguatnya lembaga seperti World Bank dan Transparency International dalam memopulerkan definisi korupsi, lahirlah paham dominan tentang korupsi sebagai varian dari pengertian "korupsi sebagai penyalahgunaan jabatan publik bagi kepentingan pribadi' (World Bank) dan 'korupsi sebagai penyelewengan kekuasaan yang dimandatkan demi keuntungan pribadi' (Transparency International) yang berdampak pada ciri teknokratik (dan karena itu, problematis) dari kebijakan dan gerakan anti-korupsi yaitu satu-model-untuksemua (hlm: 328). Sementara itu, pada bab keenam, Pendekatan Studi Korupsi, pembaca diperkaya wawasannya tentang sumbangan ilmu-ilmu sosial seperti Antropologi, Sosiologi, 
Kriminologi, dan lain-lain untuk memahami korupsi. Keragaman pendekatan ilmu-ilmu sosial di satu sisi memperkaya khazanah teoretis yang bercirikan corak observasional klaim kausalitas gejala korupsi. Di sisi lain, keragaman ini menyimpan potensi kesesatan ketika menganggap apa yang dihasilkan satu cabang ilmu sosial sebagai keseluruhan gejala korupsi itu sendiri. Salah satunya kesesatan itu berwujud dominasi pendekatan ekonomi---dengan kerangka nilai untungrugi yang bersifat finansial atau material, juga dimunculkannya permainan insentif---dalam memahami dan menentukan garis kebijakan anti-korupsi (hlm: 445).

Pada bab ketujuh, Korupsi sebagai Persoalan Moral, dibahas alasan fundamental mengapa korupsi senantiasa dipandang sebagai persoalan abadi sepanjang zaman. Satu jawaban yang cukup memuaskan berasal dari kerangka berpikir etika teleologi yang menyatakan bahwa ciri korup perbuatan terletak dalam penyelewengan alasan-adanya institusi, dan ciri moral korupsi terletak dalam penyelewengan yang membuat institusi menjauh dari alasanadanya. Korupsi adalah spesies tertentu dari sikap dan tindakan yang tidak bermoral, yang terutama dikaitkan dengan peran dan kemampuan manusia untuk bertindak (agency) dalam posisi kelembagaannya. Korupsi dengan demikian merupakan satu di antara sejumlah konsep moral yang menjaga demarkasi antara yang tertata dan kacau, yang bersih dan kotor, yang sakit dan sehat, yang bermakna dan absurd (hlm: 520).

Akhirnya, pada bab terakhir, Penutup, penulis merangkum kegelisahan pencarian intelektualnya tentang keragaman arti korupsi yang kurang-lebih berbunyi sebagai berikut: 'Korupsi merupakan problem moral yang merentang sepanjang sejarah peradaban umat manusia sejak dulu kala, sejauh masyarakat mengenal dan mengakui adanya tatanan sosial yang diidealkan di satu sisi, dan kacaunya ruang gelap yang menampung irasionalitas, absurditas, kesesatan, kekacauan, kebusukan, dan kerusakan di sisi lain.' Lanjutnya, "Luasnya korupsi berlangsung melalui dalil domino: korupsi di satu institusi terjalin dalam rantai- domino dengan praktik korupsi di institusiinstitusi lain. Penjungkirbalikan standar integritas institusional inilah yang menjadi jantung alasan mengapa konsep korupsi integral dengan cita-cita tatanan yang baik. Sejauh suatu masyarakat mempunyai paham dan cita-cita membentuk tatanan, sejauh itu pula korupsi menjadi kegelisahan abadi." (hlm: 527)

\section{Secarik catatan untuk mentasnya ruang harapan}

Secara struktur dan gaya penulisan, buku ini memiliki empat keunggulan berikut. Pertama, metodologi pembahasan dieksplisitkan sejak awal dan terus dijaga selama penelusurannya. Kedua, buku ini menggunakan pendekatan multi-perspektif dan multi-tafsir, sehingga menghasilkan kekayaan pemahaman tentang korupsi yang sedemikian kaya dan beragam. Ketiga, kritis-reflektif, penulis tidak puas berhenti pada tataran gejala, tetapi mencoba masuk ke dalam ranah substansi dengan ciri sebaran gugus pertanyaan kritis yang dinarasikan secara integral dalam lembar demi lembar tubuh tulisan. Keempat, tuturan deskriptif argumentatif yang disajikan penulis dilengkapi dan dikuatkan dengan munculnya dua buah grafik, tujuh buah tabel, sebuah diagram, dan sejumlah rumus penyederhanaan untuk memahami kompleksitas gejala korupsi, seperti rumus ekonomi prinsipal-agen (hlm: $367)$, juga rumus matematika simbolik $X$ dan $\mathrm{Y}$ untuk menjelaskan penyebab dan keluasan korupsi di Indonesia.

Ada sedikit catatan pelengkap untuk bagian penutup buku ini. Herry-Priyono mengafirmasi pentingnya menggalakkan pendidikan anti-korupsi dikarenakan "studi, penggalian, dan penelitian tentang proses pedagogis transformasi ke arah perilaku yang semakin kurang-korup ini rupanya masih menjadi wilayah yang kosong atau belum cukup ditelusuri dan didalami." (hlm: 531). Pokok ini, sayangnya, tidak diberikan ruang pembahasan tersendiri. Padahal, pendidikan sejatinya memegang kunci untuk meminimalisir kecenderungan sikap maupun perilaku korupsi pada warga negara peserta didiknya, sejauh kebijakan, proses, dan institusi pendidikan 
dalam negara tersebut tidak dijangkiti virus korupsi pada segala tingkat pemangku kepentingannya. Pandangan soal sentralitas pendidikan untuk menekan laju atau dorongan korupsi ini sudah diteliti dengan cermat oleh Eric M. Uslaner, Profesor Ilmu Pemerintahan dan Politik dari the University of MarylandCollege Park, Amerika Serikat, dalam bukunya The Historical Roots of Corruption: Mass Education, Economic Inequality, and State Capacity (Uslaner, 2017). Dengan menggunakan bukti yang diperoleh lewat pemodelan statistik dan studi kasus dari sejumlah negara di Eropa Utara dan Selatan, Asia, Afrika, Amerika Latin, Amerika Serikat, Kanada, Australia, dan Selandia Baru, hasil penelitian Uslaner kurang lebih menyimpulkan bahwa "negara-negara dengan tingkat pendidikan yang lebih tinggi pada masa lalu menghadapi lebih sedikit kasus korupsi pada masa sekarang." (Uslaner 2017: 2)

Setelah buku Korupsi: Melacak Arti, Menyimak Implikasi (Herry-Priyono, 2018) diluncurkan di Gedung Merah Putih KPK pada Kamis 13 Desember 2018, tiga bulan berikutnya, tepatnya pada Senin 18 Maret 2019, giliran buku karya Vishnu Juwono berjudul Melawan Korupsi: Sejarah Pemberantasan Korupsi di Indonesia 1945-2014 (Juwono, 2018) diluncurkan. Meskipun fokus kajian dan tingkat kedalaman pembahasan dari kedua buku ini berbeda, tetapi munculnya kedua karya ini cukup menggembirakan untuk mengisi kekosongan literatur studi yang serius tentang korupsi dan kajian anti-korupsi dalam bahasa Indonesia. Dengan semakin luas dan majunya telaah pemikiran soal korupsi, yang salah satunya dipantik oleh kemunculan adikarya Herry-Priyono ini, sebagai warga Republik Indonesia selayaknya berharap bahwa agenda pencegahan dan pemberantasan korupsi mengayun semakin komprehensif.

\section{DAFTAR PUSTAKA}

ACCH (2011). Pendidikan Antikorupsi Untuk Perguruan Tinggi. Diakses dari https://acch.kpk.go.id/id/berkas/ buku-antikorupsi / perguruantinggi/pendidikan-antikorupsi- untuk-perguruan-tinggi. Diakses pada tanggal 7 Mei 2019.

Bernie, M. (2019). “KPK Latih 139 Guru PPKN SMA di Jakarta Soal Pendidikan Antikorupsi." Diakses dari https:// tirto.id/dEsE. Diakses pada tanggal 15 Mei 2019.

Gabrillin, A. (2019). "Pimpinan KPK Sebut Agen SPAK Paling Sukses Cegah Korupsi di Indonesia." Kompas.com, 26/04/2019, 18:04 WIB. Diakses dari https://nasional.kompas. com/read/2019/04/26/18045961/ pimpinan-kpk-sebut-agen-spakpaling-sukses-cegah-korupsi-diindonesia. Diakses pada tanggal 7 Mei 2019.

Herry-Priyono, B. (2018). Korupsi: Melacak Arti, Menyimak Implikasi. Jakarta: Gramedia Pustaka Utama.

Juwono, V. (2018). Melawan Korupsi: Sejarah Pemberantasan Korupsi di Indonesia 1945-2014. Jakarta: Kepustakaan Populer Gramedia.

Transparency International. (2018). Cek Data: Tren Membaik Indeks Persepsi Korupsi di Indonesia, Indeks Persepsi Korupsi Indonesia 1995-2018. Diakses dari https:/ / databoks.katadata.co.id/ datapublish/2019/03/30/cek-datatren-membaik-indeks-persepsikorupsi-di-indonesia. Diakses pada tanggal 7 Mei 2019.

Uslaner, E. M. (2017). The Historical Roots of Corruption: Mass Education, Economic Inequality, and State Capacity, Cambridge (UK): Cambridge University Press.

Zain, F. M. (2019). “Untuk Pertama Kalinya, Pendidikan Antikorupsi di Sekolah di Terapkan di Jateng." Kompas. com, 08/04/2019, 10:48 WIB. Diakses dari https://regional.kompas. com/read/2019/04/08/10480651/ untuk-pertama-kalinya-pendidikanantikorupsi-di-sekolah-di-terapkandi. Diakses pada tanggal 7 Mei 2019. 